\title{
MEDIDA PROVISÓRIA 746/2016: A CONTRA-REFORMA DO ENSINO MÉDIO DO GOLPE DE ESTADO DE 31 DE AGOSTO DE 2016
}

\section{RESUMO}

\author{
Marise Nogueira Ramos ${ }^{1}$ \\ Gaudêncio Frigotto ${ }^{2}$
}

O objeto específico de análise deste texto é a Medida Provisória n. 746/2016, convertida no Projeto de Lei n. 34/2016, aos quais se somam a Portaria do Ministério da Educação n. 1.145/2016 e o Projeto de Lei 867/201, entendendo-os como a contra-reforma na educação do Golpe de Estado de 31 de agosto de 2016. Trata-se de um ataque desferido contra as últimas conquistas do ensino médio na perspectiva da formação unitária e integrada dos jovens brasileiros. Retoma-se, de forma mais regressiva, princípios da Reforma Capanema dos anos de 1940 e das Leis n. 5.692/1971 e 7.044/1982, produzidas igualmente em contextos anti-democráticos. Tais medidas do passado e do presente correspondem, no plano da cultura, ao movimento da economia marcada pela contradição capital e trabalho. Por estar inserida num contexto de acelerados acontecimentos no país, e revelando, na conjuntura, elementos da estrutura econômico-social, o estudo sobre a contra-reforma atual se situa campo da história do tempo presente, ainda que não tenhamos a pretensão do trabalho específico dos historiadores. Argumentamos que o Golpe de Estado reitera nossa história de rupturas democráticas, com determinações econômicas e consequências na educação: a negação aos estudantes brasileiros do pleno direito à educação básica.

Palavras-chave: Medida Provisória 746/2016; Contra-reforma do ensino médio; Golpe de Estado.

\section{PROVISIONAL MEASURE N. 746/2016: A COUNTER-REFORM IN THE SECONDARY EDUCATION OF THE COUP D'ÉTAT OF AUGUST 31, 2016}

\begin{abstract}
The specific object of analysis of this text is the Provisional Measure n. 746/2016, converted into Project of Law n. 34/2016, to which areadded the Ordinance of the Ministry of Education n. 1.145/2016 an the Project of Law 867/201, understanding them as a counterreform in the education of the coup d'état of August 31, 2016. This is an attack on the last achievements of secondary education in the perspective of unitary and integrated education of Brazilian youth. The principles of the Capanema Reform of the 1940s and Laws n. 5692/ 1971 and 7044/1982, also produced in anti-democratic contexts, are recouvered. Such measures of the past and of the present correspond, at the level of culture, to the movement of the economy marked by the contradiction of capital and labor. Because it is inserted in a context of accelerated events in the country, and revealing, in the conjuncture, elements of the economic-social structure, the study on the current counter-reform is into a field of the history of the present time, although we do not have the pretension of the historians specific work. We argue that the coup reiterates our history of democratic ruptures, with economic determinations and consequences in education: denying Brazilian students the full right to basic education.
\end{abstract}

Keywords: Provisional Measure n. 746/2016 ; Counter-reform in the secondary education ; Coup d'état. 


\section{Introdução}

Quase sempre a arte tem, melhor que a ciência, a capacidade de expressar a contundência e as consequências de um determinado acontecimento histórico. $\mathrm{O}$ documentário de Danilo Tavares - "Um dia que durou vinte e um anos" - juntou rigorosa pesquisa documental, base para a ciência da história, e os recursos da arte para identificar os grupos, os interesses e os mecanismos utilizados pela Classe dominante brasileira, com apoio externo, em especial o império Norte Americano, na construção e consumação da ditadura empresarial militar de 1964.

As últimas três décadas, com marcas próprias, perfilaram movimentos, lutas, avanços e recuos na construção democrática do Estado de direito. A constituição de 1988 expressa positivamente a década de 1980 nesta processualidade. Todavia, na década de 1990 instaurase o projeto neoliberal e a venda do patrimônio púbico. Os governos Luiz Inácio Lula da Silva e Dilma Rousseff, mesmo sem efetivarem reformas estruturais, estabeleceram ganhos reais no salário mínimo e mediante políticas sociais de transferências de renda tiraram da miséria mais de 20 milhões de brasileiros, facultaram o acesso ao ensino médio e superior a grupos antes excluídos e pautaram uma política externa de maior autonomia em relação ao imperialismo Norte Americano.

Processo interrompido por um novo Golpe de Estado que reitera o passado com novas determinações, conformando, nos termos de Giorgio Agamben (2004) um Estado de Exceção e mantendo apenas formalmente o Estado de direito. Um golpe, portanto, que interrompe o jogo democrático.

Certamente o passar dos anos nos darão elementos para a compreensão mais aguda das consequências do atual golpe contra os direitos da classe trabalhadora. As ditaduras e golpes de Estado em nossa história sempre se deram para defender os interesses da classe dominante e, portanto, para retirar, pela força da violência das armas ou arbítrio da lei, ou ambas conjugadas, direitos da classe trabalhadora. Em nome do ajuste no passado e da austeridade no presente, efetivam-se reformas que, abruptamente, retiram direitos e aumenta a exploração dos trabalhadores.

De forma célere, o golpe de 31 de agosto de 2016 articula a PEC 55, já aprovada, com as tão ou mais drásticas reformas da previdência e trabalhista. Concomitantemente a estas reformas, sempre que há golpes há mudanças mais ou menos profundas no campo educativo. A ditadura empresarial militar de 1964, ao longo de sua duração, efetivou reformas, sob o ideário da ideologia do capital humano, da pré-escola à pós-graduação. Na década de 1990, sob o autoritarismo do projeto neoliberal, impediu-se a aprovação da LDB construída no debate amplo na sociedade e foram sendo tomadas as medias ad hoc pautadas pelos organismos internacionais, dos quais o ex Ministro Paulo Renato de Souza e grande parte de sua equipe tinham sido ou eram membro ativos. Equipe que volta a comandar de fato o MEC nas políticas educacionais, mormente do ensino médio, dentro do Golpe de Estado.

Na presente análise, nos situamos no campo da história do tempo presente, mas cujas mediações remontam a processos de médio ou longo prazo. Por tratarmos de um acontecimento em ebulição e acelerado em sua virulência e sem a pretensão do trabalho específico dos historiadores, cabe iniciarmos com uma breve consideração metodológica sobre história em processo. Também, de forma breve e na compreensão da nota metodológica, assinalarmos o que este Golpe de Estado reitera em nossa história de rupturas democráticas e o que ele traz de novo, com consequências mais profundas no campo econômico social e sua relação com a educação. O ponto central da análise é a contrareforma $^{3}$ do ensino médio proposta pela Medida Provisória n. 746/2016, transformado em 
Projeto de Lei de Conversão n. 34/ 2016 ${ }^{4}$, em conjunto com a Portaria do Ministério da Educação n. 1.145/20165, a qual institui o "Programa de Fomento à Implementação de Escolas de Tempo Integral" criado pela referida Medida Provisória. Destacaremos as alterações que demarcam seu caráter anacrônico e regressivo de forma acumulativa em relação a outros momentos históricos autoritários.

Por fim, a título de conclusões, explicaremos a relação entre as reformas no âmbito econômico-social e trabalhista em curso; a criação de lei que oficializa o pensamento único - ideário do conhecimento e ensino neutros - pelo PL 867/2015que, não sem cinismo e com o ardil da linguagem manipulada, se apresenta sob o nome de Escola sem Partido; e a contrareforma do ensino médio.

\section{História em processo: unidade diversa entre presente e passado.}

Os homens fazem a sua própria história, mas não o fazem arbitrariamente, nas condições escolhidas por eles, mas nas condições dadas diretamente e herdadas do passado. (Karl Marx)

A epígrafe acima expressa com precisão a questão dos elos inseparáveis e, ao mesmo tempo as tensões, entre a história do presente, que busca entender acontecimentos e fatos que confrontam interesses antagônicos de classe e grupos sociais no seu desenrolar imediato e seus vínculos orgânicos necessários e inseparáveis herdados do passado. Trata-se de uma indicação que é feita por Marx justamente na introdução do texto "O 18 Brumário de Luiz Bonaparte" no qual, como nos textos "A Luta de Classe na França" e "A Guerra Civil na França", analisa a história no pulsar dos fatos acontecendo nos embates diários.

O sentido marxista de história em processo que orienta nossa análise da contrareforma do ensino médio, expressão dos interesses da classe dominante brasileira artífice do Golpe de Estado formalmente sancionado em 31 de agosto de 2016, é destacado na coletânea organizada por Florestan Fernandes (1989): "Marx Engels História”. Destacamos aqui dois comentários de Florestan, o primeiro relativo ao "O 18 Brumário" e o segundo, do texto "A luta de classe na França" de 1848 a 1850:

História em processo evoca uma maneira de apanhar a história em seu movimento de vir-a-sercotidiano (ou seja, como ela brota aos "nossos olhos"; ou se desenrolou num presente vivido e em um passado que possa ser descrito "dinamicamente". A História em processo é (...) a história dos homens, o modo como produzem socialmente a sua vida, ligando-se ou opondo-se uns aos outros, de acordo com sua posição nas relações de produção, na sociedade e no Estado, e gerando, assim, os eventos e processos históricos que evidenciam como a produção, a sociedade e o Estado se preservam ou se alteram ao longo do tempo. (Grifos do autor) (FERNANDES, 1989, p.47)

No segundo comentário, destaca a insistência de Engels em diferentes momentos e na introdução de 1895 de "A luta de Classe na França", sobre o peso das determinações econômicas no processo histórico e, ao mesmo tempo, a dificuldade de apreender a sua complexidade por serem estas que acabam definindo (em última instância) as mudanças no Estado e no conjunto das instituições da sociedade.

$\mathrm{Na}$ apreciação dos acontecimentos das séries de acontecimentos da história diária, jamais podemos retomar às últimas causas econômicas ${ }^{6}$. Nem 
sequer hoje, quando a imprensa especializada subministra materiais tão abundantes, seria possível mesmo na Inglaterra acompanhar dia a dia a marcha da indústria e do comércio no mercado mundial e as mudanças operadas nos métodos de produção a ponto de poder, em qualquer momento, fazer-se um balanço geral destes fatores infinitamente complexos e constantemente em transformação; fatores dos quais os mais importantes agem quase sempre, além disso, de maneira encoberta, antes de se manifestarem de súbito e com violência na superfície.( Grifos nossos) (ENGELS, apud FERNANDES, op.cit. p. 60)

A história em processo na apreensão dos fatos presentes não se descola, pois das mediações e determinações mediatas ou remotas herdadas do passado. Assim, ao analisar fatos do presente, o que conta é a experiência biográfica dos que a produzem e o apoio em fontes escritas ou orais, em documentos que permitem apreender as determinações, especialmente, de um passado de curta e média duração ${ }^{7}$. Isto não elide que, em determinados aspetos da análise os autores se valham de fontes que mostram o que é estruturalmente reiterado na história de uma determinada nação.

Maria Ciavatta, em texto em que debate as questões e diferentes perspectivas em relação à história do tempo presente, em consonância com que expusemos acima, nos oferece a síntese que expressa a direção da análise que buscamos empreender.

A concepção de história do presente tem diversas vertentes de interpretação. Do ponto de vista metodológico, ela supõe todo o rigor de qualquer trabalho de história. A denominação história do presente não altera o curso da velocidade dos acontecimentos, vistos como presentismo, nem a natureza das conjunturas, as diversas temporalidades geradas na vida social. (CIAVATTA, 2016, p.9).

Com esta breve sinalização metodológica buscamos situar os leitores sobre a natureza e sentido deste texto cujo foco é o presente imediato, mas que busca determinações com fontes de médio prazo e, no caso do atual Golpe de Estado, referencias de longa duração.

\section{O Golpe de Estado de 31 de agosto: o que se reitera e o que é novo e se aprofunda.}

Está no DNA da classe dominante brasileira, que historicamente derruba, pelas armas se for preciso, toda ameaça ao seu domínio, seja qual for sua sigla. (Luiz Fernando Veríssimo) ${ }^{8}$

A frase acima, de uma crônica em que Veríssimo explicita o clima de ódio expresso nas manifestações de rua a partir de 2014 favoráveis ao afastamento da presidenta Dilma Rousseff, capta o elo mais profundo entre o passado e o presente das ditaduras e golpes da classe dominante brasileira. Trata-se do DNA de uma classe que incorporou as estratégias de violência e extermínio dos colonizadores, cuja expressão máxima se patenteia no genocídio dos povos originários e em quase quatro séculos de escravidão.

Alfredo Bosi, na sua obra Dialética da Colonização, referindo-se ao século XIX, mostra a gênese deste DNA da classe dominante brasileira: "O que atuou eficazmente em todo o período de construção do Brasil como Estado autônomo foi um ideário de fundo conservador; no caso, um complexo de normas jurídico-políticas capazes de garantir a propriedade fundiária e escrava até seu limite possível" (BOSI, 2010, p. 195). A escravidão durou quase quatro séculos e, mesmo juridicamente abolida em 1888 permanece, entretanto, nas relações sociais, de modo que, no caso dos negros, pretos e pardos, até hoje, à 
desigualdade de classe soma-se o preconceito "racial". Florestan Fernandes (1964) e Otávio Ianni (1962,1987 e 1988) nestas obras dissecam analiticamente esta perversa relação. Isto mostra-se nas estatísticas sobre o emprego, a desigualdade de salários, o acesso à educação etc.; e na população carcerária que, em sua maioria, é de jovens pretos ou pardos e com nível de escolaridade que, para a grande parte, não passa do ensino fundamental.

Esta marca de relações políticas e jurídicas da classe dominante brasileira conformara, ao longo do século XX, um projeto societário que Florestan Fernandes (1968, 1973 e 1974), de forma original, o definiu como capitalismo dependente. Um projeto societário onde a classe burguesa brasileira se associa aos centros hegemônicos do capital mundial para manter uma das sociedades de maior concentração de propriedade e riqueza na mão de uma minoria e a manutenção da pobreza e miséria da maioria. Uma classe que é anti-nacional, anti-povo e anti-educação púbica universal, gratuita, laica e unitária para todos.

As duas ditaduras e os diversos golpes institucionais ao longo do século $\mathrm{XX}$ se impuseram para manter os privilégios da classe burguesa brasileira que Florestan Fernandes denominou como uma "minoria prepotente. Não foi um erro confiar na democracia e lutar pela revolução nacional. $\mathrm{O}$ erro foi outro - o de supor que se poderiam atingir esses fins percorrendo a estrada real dos privilégios na companhia dos privilegiados. Não há reforma que concilie uma minoria prepotente a uma maioria desvalida" (FERNANDES, 1977, p. 245) Três décadas depois do fim da ditadura empresarial militar há um novo golpe para manter os interesses e privilégios desta minoria prepotente. A PEC 55 é a tradução material em nome de quem e para que foi construído e deflagrado mais este Golpe de Estado. Esse é, pois, o traço mais profundo do que se reitera nas ditaduras e nos golpes na nossa história.

Reiteram-se, também, as estratégias para ganhar mentes e corações mediante argumentos e apelos morais. Deus, família, pátria contra o comunismo no golpe de 1964. No atual golpe novamente Deus, família são invocados cinicamente pelos deputados na votação no Congresso e por Janaina Paschoal, coautora da denúncia que abriu o processo de impeachment, durante o julgamento no Senado. Reitera-se, igualmente o papel demolidor, parcial dos conglomerados da mídia empresarial, tal como em 1954, com Getúlio Vargas, em 1964 com o poder empresarial-militar e, atualmente, de forma mais intensa e menos dissimulada, com o poder empresarial-midiático. Sem dúvida, a mídia empresarial sempre foi o partido ideológico dos golpes e de sua manutenção até o limite. Reitera-se, por fim, a aliança com os interesses do imperialismo Norte Americano. A burguesia brasileira, como classe anti-nação e construtora de um projeto societário de capitalismo dependente, sempre armou os golpes coma participação dos Estados Unidos.

O que é novo atualmente é o fato de que, diferentemente dos golpes anteriores, a classe dominante brasileira estruturou-se organicamente e, mesmo com dissensos e competições de interesses dos diferentes setores, defende o projeto da classe no seu conjunto. Assim, se sempre tiveram o Estado no sentido stricto (parlamento, executivo e judiciário) ao longo dos últimos cinquenta anos, os grandes grupos econômicos da indústria, comércio, serviços, capital financeiro e agronegócio construíram seus aparelhos de hegemonia na sociedade civil.

Ainda que não seja nova atuação de parte do poder judiciário na história dos golpes, nova foi a politização da justiça, mormente por parte do Ministério Público. A condução seletiva na operação Lava Jato, até o presente, focando determinados partidos e não outros, explicita esta politização. Novo é o fato de a classe dominante não ter recorrido às Forças Armadas no atual golpe. Entretanto, não dispensou o poder de coação de setores armados, agora pelo papel autônomo assumido pela Polícia Federal. Isto dá ao golpe uma face obscura e perigosa como indica Giorgio Agamben, quando analisa o tema da "polícia soberana" 
(2004, p. 97-100). Agamben mostra que a partir da Guerra do Golfo a polícia passou a atuar criminalizando antes para depois condenar não respeitando os princípios do Estado de Direito $^{10}$.

No momento em que assumiu o governo, Luiz Ignácio Lula da Silva, mesmo assinando a Carta ao povo brasileiro, com a qual anuncia que seu governo não faria rupturas com os interesses maiores da classe dominante, sabia-se que as forças sociais que o elegeram certamente o pressionaria para alguns direitos até então negados. Com efeito, mesmo sendo governos de conciliação, as políticas sociais e, em particular, a recomposição e aumento do salário mínimo ao longo de mais de uma década nos governos Lula da Silva e Dilma Rousseff, avançaram além do suportável para uma classe dominante de DNA escravista e colonizador e, num momento de crise mundial profunda do sistema capital, já que não conseguiram assumir o poder pelo voto popular, o tomaram por meio de um Golpe de Estado. O componente externo que compõe a motivação do golpe situa-se na ruptura relativa da dependência do império Norte Americano mediante a política de unidade da América Latina e pela ativa participação do Brasil na criação do grupo de países, BRICS (Brasil, Rússia, Índia, China e África do Sul), que firmaram um acordo de cooperação política e econômica.

O âmbito onde a organicidade de classe melhor se explicita é o campo da educação, terreno da formação das novas gerações. Com efeito, não por acaso, o Movimento Escola sem Partido começou em 2004 e o Movimento Todos pela Educação em 2005 - ainda que oficializado em 2006 no lançamento do Plano de Desenvolvimento da Educação (PDE). O primeiro foi elaborando e explicitando o sentido contrário de como se define. Vale dizer, a ideologia do partido do pensamento único - da neutralidade do conhecimento, do ensino e da educação, mas acrescido, agora, da intolerância e ódio ao diferente. $\mathrm{O}$ segundo, criado por catorze dos maiores grupos econômicos ligados à indústria, ao capital financeiro e ao agronegócio; e por dezoito parceiros, estes operadores, em especial nos sistemas municipais e estaduais de educação na disputa concreta do conteúdo, métodos e valores que interessam ao mercado. Após o Golpe de Estado, seu ideário tronou-se política do governo tendo como operadora a Secretária Geral do Ministério da Educação e sua equipe.

A escolha e a natureza da imposição arbitrária da contra-reforma do ensino médio, o qual expressa uma disputa desde a década de 1930, não é, também, por acaso. Nada mais claro do que indica Florestan Fernandes, ele um grande defensor da escola pública, sobre a relação entre dominação econômica, cultural e educacional: "A dominação imperialista não deixa claros. Ao fechar o tempo histórico no plano da economia, ela também fecha o tempo histórico no plano da cultura" (FERNANDES, 1977, p 230).

\section{Medida Provisória 746/2016 e a Contra-Reforma do Ensino Médio: retrocesso dos retrocessos}

O campo jurídico não é o que acredita ser, isto é, um universo puro de todo comprometimento com as necessidades da política ou da economia. Mas o fato de que consiga fazer-se reconhecer como tal contribui para produzir efeitos sociais inteiramente reais e, em primeiro lugar, sobre os que têm por profissão dizer o direito. (Bourdieu, 1997, p. 116)

Antônio Gramsci (1991) discutiu o papel da imprensa na construção da hegemonia, processo pelo qual a dominação é exercida não pela violência, mas sim pela obtenção do consenso. Pierre Bourdieu (1997), por sua vez, escreveu um importante ensaio "Sobre a 
Televisão", no qual demonstra a influência econômica que sofrem os meios de comunicação e também como intelectuais que não são plenamente reconhecidos no seu campo utilizam os espaços da televisão para obterem o reconhecimento da população abordando questões complexas de forma simplória e em linguagem coloquial.

A divulgação da contra-reforma do ensino médio em curso no Brasil pela televisão expressa a correção dessas análises. Tão logo a Medida Provisória n. 746, de 22/09/2016 foi publicada, a TV Cultura proporcionou ao atual titular da pasta ministerial da Educação o lugar central no Programa Roda Viva e, em torno dele, alguns intelectuais representantes do pensamento empresarial na Educação. Citamos, por exemplo, Guiomar Namo de Mello, falando em nome do Grupo Civita e Mozart Neves Ramos, pela Fundação Ayrton Sena. A primeira, não por acaso, teve papel importante no governo de Fernando Henrique Cardoso (FHC) ocupando uma cadeira no Conselho Nacional de Educação (CNE) o que a legitimou como relatora das Diretrizes Curriculares Nacionais do Ensino Médio ${ }^{11}$ (DCNEM) baseadas na Pedagogia das Competências, na política desse período, cujo ícone foi o Decreto $\mathrm{n}$. 2.208/97. O segundo, conterrâneo de Mendonça, exerceu importantes funções públicas, como a reitoria da Universidade Federal de Pernambuco, a titularidade da Secretaria de Educação do mesmo Estado e também foi membro do CNE, contraditoriamente no mandato que aprovou as DCNEM ${ }^{12}$ vigentes, com perspectivas bem diferentes das anteriores, por tentarem coerência com a concepção de Ensino Médio Integrado ${ }^{13}$. Seu destaque na gestão pública o levou também a presidir o Movimento (empresarial) "Todos pela Educação". Nesse programa, a maioria dos participantes aplaudiu a atual proposta de mudança do ensino médio e os telespectadores ainda puderam ouvir da ex-conselheira que o conteúdo da MP recupera a supostamente avançada política de ensino médio do governo de FHC, interrompida pelos governos do Partidos dos Trabalhadores.

$\mathrm{O}$ grupo que assumiu o MEC no atual governo argumenta que o ensino médio no Brasil é o principal desafio da educação brasileira, com um quadro de estagnação das matrículas, a existência de mais de um milhão de jovens de 15 a 17 anos fora da escola. Apresenta, ainda, um dado de pesquisa da Fundação Getúlio Vargas de que 40,3\% desses jovens apresentam a falta de interesse no ensino médio como motivo. Resolve, assim, reformar o ensino médio por meio da Medida Provisória.

Antes de se falar de seu conteúdo, é importante destacar a forma autoritária que se revela neste ato e que tem sido a marca deste governo. O dispositivo Medida Provisória se aplica a situações de emergência nas quais o executivo tem a prerrogativa de tomar uma decisão, sob a condição de que esta seja afirmada ou rejeitada, no todo ou em parte, mediante a sua conversão em Projeto de Lei, ou mesmo não sendo apreciada pelo Congresso Nacional no prazo regimentalmente definido para tais casos. Ora, o ensino médio dispõe de uma legislação completa e atual. Citamos pelo menos duas, a saber: a) a LDB em seu conteúdo original aprovado em 1996 e com as revisões posteriores, dentre as quais a que incorpora a integração da educação profissional ao ensino médio, inicialmente instituída pelo Decreto $\mathrm{n}$. 5.154/2004 que revogou o 2.208/97 da era FHC e levada à LDB pela Lei 11.741/2008; b) as atuais DCNEM (Parecer n. 05/2011 e Resolução n. 2/2012, do CNE), um dos textos mais avançados que regulamenta o ensino médio, no qual estão presentes os princípios educativo do trabalho e pedagógico da pesquisa, a valorização do protagonismo juvenil, a importância da interdisciplinaridade e da integração entre trabalho, ciência e cultura no currículo ensino médio.

É exatamente este conteúdo, o qual persegue a formação integral dos educandos nesta etapa da educação básica, que a MP quer desconstruir, em nome não só da restauração da concepção reducionista, fragmentária e pragmática da política de ensino médio de FHC, como nos declarou na televisão a relatora das DCNEM revogadas, mas fazendo-se pior, pois 
a proposta atual extrai, em quantidade e em qualidade, o conteúdo efetivamente formativo dos estudantes do ensino médio. A intenção de desconstrução, então, provoca um artefato uma suposta crise do ensino médio para a qual ainda não se teria proposta de solução (uma inverdade, pois os documentos citados comprovam a consistência das políticas implementadas de 2003 até $2015^{14}$ nesse sentido) a partir do qual se produz o fato - a suposta necessidade de reformulação do ensino médio. Explicita-se, assim, a fórmula do autoritarismo que subjaz à publicação de uma MP com este fim.

Há, ainda, uma idiossincrasia jurídica no conteúdo da MP, pois ela legisla tendo como referência algo ainda inexistente, qual seja, a Base Nacional Comum Curricular (BNCC). O movimento de elaboração deste dispositivo foi impulsionado pela interpretação, por gestores do MEC - ainda no primeiro mandato da Presidenta Dilma Rousseff - de Secretarias de Educação e também de alguns pesquisadores em Educação, de que a LDB determinaria a necessária existência de tal base curricular, como atribuição do Ministério, ouvido o CNE.

Outros setores do campo, a exemplo da Associação Nacional de Pós-Graduação e Pesquisa em Educação e pesquisadores implicados com o tema, já interpretavam que tal determinação da lei já fora cumprida na forma das DCNEM, inclusive remetendo aos sistemas de ensino a possibilidade de complementá-la para atender o que seria a parte diversificada do currículo. Tal polêmica, entretanto, não impediu que o MEC levasse adiante a primeira interpretação, vindo a elaborar um documento com aquela denominação (BNCC) pelas mãos de intelectuais convidados para este fim e participação dos sistemas de ensino mediante as chamadas "consultas públicas".

O movimento "Escola sem partido" chegou a questionar sobre a legitimidade dos sujeitos que assumiram tal elaboração, certamente considerando seus adeptos como os mais legítimos (o documento apresentaria muito conteúdo político, especialmente na área de Ciências Humana e Sociais). Ao mesmo tempo, a nova conjuntura provocou mudanças na composição do grupo que liderava a elaboração do documento, mas não interrompeu o processo, previsto para ser concluído no primeiro semestre de 2017.

Vê-se, assim, o caráter manipulatório da publicação antecipada da MP em relação à conclusão da BNCC, dada a influência de seu conteúdo pelo ideário conservador da MP, a qual foi convertida no Projeto de Lei. n. 34/2016. Trata-se, assim, de um movimento que tem na caneta do executivo a sua objetividade, mas na verdade representa a vontade de conservadores na sociedade brasileira. A contra-reforma é expressão do pensamento conservador, valendo-se de uma lógica economicista e pragmática expressiva de nosso capitalismo dependente, em um tempo de hegemonia neoliberal e cultura pós-moderna; a cultura do fragmento, do imediato, do utilitário e do enxuto. Trata-se de uma política que liofiliza a educação básica retirando-lhe conteúdo de formação científica e ético-política que se esperaria numa sociedade que tem as pessoas e não o mercado como a razão da política pública.

Discutido o método da contra-reforma, passemos ao seu conteúdo, inicialmente de cunho ideológico que adquire conotação técnica na forma dos artigos reformuladores da LDB. Valendo-se da estratégia televisiva de construção do consenso, não foi somente um espaço considerado culto ocupado por intelectuais, como o programa Roda Viva da TV Cultura, que o bloco no poder usou para divulgar e valorizar as propostas de mudança no ensino médio. A linguagem simples, veiculada por jovens sorridentes, demonstrando satisfação por um ensino médio em que eles poderiam "escolher o que gostam", "estudar o que interessam" entra pelos lares dos brasileiros com suas televisões ligadas, prometendo a solução para esse "grande problema" que é o ensino médio. Seriam os jovens da propaganda televisiva do governo federal reais representantes da juventude brasileira? $\mathrm{O}$ atendimento 
aos interesses dos jovens é o grande mote dessa contra-reforma, argumentando-se que o ensino médio não os incorpora. Mas, quais são os interesses dos jovens e qual a relação entre esses e a educação básica? Apela-se para o interesse dos jovens como argumento, mas sem qualquer discussão com educadores, famílias e com os próprios estudantes sobre o significado da suposta falta de interesse e suas possíveis soluções.

Como assinalamos, pesquisas demonstram e a sociedade não desconhece o problema da qualidade das escolas dos sistemas estaduais de ensino, responsáveis pela oferta do ensino médio, especialmente quanto à infraestrutura (salas de aulas precárias, falta de bibliotecas, laboratórios, auditórios, quadras esportivas etc.), às condições de trabalho docente (nas quais se incluem carga horária letiva elevada, não dedicação exclusiva a uma escola, baixos salários, dentre outros). Esta realidade, de fato, torna a escola pouco atrativa aos estudantes, o que é apropriado pelo discurso dos contra-reformadores como um desinteresse em geral pelo ensino médio. Isto não é verdade, pois o que o jovem não quer é a escola depredada, a escola sem condições dignas de estudo e de permanência. $O$ jovem não quer o ensino médio de baixa qualidade.

O conteúdo da MP é enunciado no caput, primeiramente como a instituição da Política de Fomento à Implementação de Escolas de Ensino Médio em Tempo Integral, secundarizando a alteração da LDB e a Lei do Fundeb (Lei n. 11.494/2007). O Projeto de Lei de Conversão (PLC) n. 34/2016 altera, corretamente, a ordem dos enunciados no caput, mas ambas tratam no primeiro artigo, da alteração do artigo 24 da LDB, referente à carga horária mínima anual dos ensinos fundamental e médio, incluindo o primeiro parágrafo que determina a ampliação progressiva, no ensino médio, para mil e quatrocentas horas, equivalente à ampliação para oito horas diárias de escola. $\mathrm{O}$ fomento à implementação de escolas em tempo integral é mantido no PLC.

A manipulação jurídica se vê mais uma vez quando o MEC publica, em 10 de outubro de 2016, a Portaria Ministerial n. 1.145 para instituir tal política (nela denominada de Programa), explicitamente tendo por base a MP. Ou seja, mesmo sendo "provisória", a medida vai adquirindo concretude de modo a sugerir a inexorabilidade da aprovação e vigência de seu conteúdo.

Não poderíamos ser contrários imediata e absolutamente ao horário escolar integral. Pode-se considerar, inclusive, que a escola é o melhor lugar para que os jovens permaneçam ao longo da semana. Porém, perguntamos em que condições e com que finalidades. Ao longo dos textos legais a questão se esclarece e, mais ainda, a portaria do horário integral. A extensão da jornada escolar visaria, basicamente, o reforço de Língua Portuguesa e Matemática, certamente para responder aos preceitos das avaliações internacionais. A interpretação não é descabida de fundamento pois, no mesmo dia em que a referida portaria é publicada, institui-se também, para o Ensino Fundamental, por meio da Portaria n. 1.144, o "Programa Novo Mais Educação", que, "visa melhorar a aprendizagem em Língua Portuguesa e Matemática" nessa etapa da educação básica, diz o caput e o respectivo artigo $1^{\circ}$., também ampliando a carga horária escolar.

Em síntese, o fato de reconhecermos plenamente a relevância inconteste da formação dos estudantes nessas áreas, não torna as demais negligenciáveis. Porém, é isto que faz a contra-reforma, pois a MP retira a obrigatoriedade dos ensinos de Artes, Educação Física, Sociologia, Filosofia e estudos da História da África e cultura afro-brasileira, importantes conquistas acrescidas ao texto original da LDB. Apesar de a obrigatoriedade das duas primeiras ser recuperada no PLC, o mesmo não ocorre com as demais. Assim, salvo se constarem da BNCC - e não sabemos em que perspectiva, face à hegemonia conservadora - seus conteúdos serão negados aos jovens tal como o foram na ditadura civil-militar. 
Reitera-se com isto, uma tendência: os resultados da avaliação suplantam a importância da própria formação.

Tais medidas somente introduzem a violência desferida contra a dura conquista do ensino médio como educação básica universal para a grande maioria de jovens e adultos, cerca de $85 \%$ dos que frequentam a escola pública. Uma agressão frontal à Constituição de 1988 e à Lei de Diretrizes e Bases da Educação Nacional, que garantem a universalidade do ensino médio como etapa final de educação básica a que todos têm direito. Nesse sentido, até o último ano da educação básica e, no caso do ensino médio, ao longo das suas 2.400 horas até então determinadas pela LDB, haveria que se ter princípios curriculares e conteúdos comuns que abrangessem universalmente os estudantes. Isto não elide a diversidade, a qual, por sua vez, só adquire sentido quando sustentada por uma concepção unitária da formação. Mas os dispositivos legais em questão retiram da formação geral comum do currículo do ensino médio inicialmente metade e posteriormente, um quarto da carga horária definida pela LDB (a MP dizia que a carga horária correspondente à BNCC não poderia ultrapassar 1400 horas e no PLC este limite foi ajustado para 1800 horas).

As demais horas curriculares corresponderão aos itinerários formativos, "que deverão ser organizados por meio da oferta de diferentes arranjos curriculares, conforme a relevância para o contexto local e a possibilidade dos sistemas de ensino" (artigo $4^{\circ}$. do PLC 34/2016, que emenda o artigo 36 da LDB). Listam-se, então, os possíveis itinerários formativos, a saber: I - linguagens e suas tecnologias; II - matemática e suas tecnologias; III - ciências da natureza e suas tecnologias; IV - ciências humanas e sociais aplicadas; V formação técnica e profissional". A ampliação da carga horária anual para as 1400 horas na forma do horário integral não se aplica ao conjunto dos conteúdos da BNCC, mas somente aos de Língua Portuguesa e Matemática (deduz-se do parágrafo primeiro do inciso IV do artigo $7^{\circ}$. da Portaria 1.145/2016, referente à implementação do horário integral, que a jornada escolar semanal seria ampliada no mínimo para 37,5 horas, sendo cinco horas destinadas à Língua Portuguesa, cinco horas à Matemática e oito horas ao que é chamada de "parte flexível", possivelmente os referidos itinerários). Comprova-se, assim, a finalidade do reforço daqueles componentes curriculares visando ao êxito nas avaliações internacionais e da especialização nos itinerários, às custas da formação básica comum.

Sem fazer considerações sobre o retorno da complementação "e suas tecnologias" às respectivas áreas que caracterizam os itinerários, uma terminologia inaugurada pelas DCNEM revogadas, ou mesmo sobre o adjetivo "aplicadas" ao se referir às ciências humanas e sociais, termos que remetem ao pragmatismo na educação, é importante ver a regressão à lógica da Reforma Capanema da Era Vargas, pela qual os estudantes escolheriam suas áreas de "vocação": os ramos científico e clássico no ciclo ginasial. Isto resultou gerações divididas em dois grupos, a saber: os que nunca haviam estudado química e física, por exemplo; e os que nunca estudaram sociologia e filosofia, dentre outros conhecimentos das ciências humanas. A formação técnica e profissional, por sua vez era a opção para os pobres, regulamentada pelas demais leis orgânicas (dos ensinos comercial, industrial e normal). Gerações divididas conforme a dinâmica econômica e sujeitos partidos em suas capacidades e realizações.

O mesmo ocorreu com lei da ditadura civil-militar, a 5.692/71 e mais especialmente com a que lhe seguiu, a 7.044/82, a partir da qual a formação técnica e profissional torna-se um dos ramos (ou itinerários para atualizar a linguagem aos novos tempos), igualmente destinados aos mais pobres. Estudantes esses que também não puderam estudar Sociologia e Filosofia e conhecerem História, Geografia nos limites que não provocassem a leitura crítica da sociedade, esta disciplinada, ainda, pelos estudos da Moral e Cívica. 
Quando se consegue caminhar um pouco na tentativa de superação das dualidades, fragmentações e reduções, ao se fazer constar do parágrafo $2^{\circ}$. do artigo 36 da LDB que o ensino médio, atendida a formação básica dos educandos, poderia prepará-los para o exercício de profissões técnicas, temos uma regressão com a reforma de FHC, sob a ditadura do mercado, quando este, após ter derrotado, com a aprovação de lei n. 9.394/1996, o projeto de LDB discutido com a sociedade, exara o Decreto n. 2.208/97 que torna a formação técnica e profissional um itinerário separado, paralelo ou posterior ao ensino médio. Quando, ainda, mais à frente, esta formação volta a poder fazer parte do ensino médio sem prejuízo da formação geral, mas, ao contrário, organicamente integrada a esta pela relação entre trabalho, ciência e cultura, na perspectivada educação politécnica e omnilateral, a classe dominante se organiza para desconstruí-la, criando os artefatos que sustentam os argumentos da atual contra-reforma e o próprio fato objetivado nos instrumentos legais em análise. Temse, aqui, a regressão das regressões.

A prerrogativa de definição do itinerário a ser oferecido aos estudantes é do sistema de ensino, conforme contexto local e suas possibilidades. Não há dúvidas de que um dos principais parâmetros que definirão tais possibilidades será a disponibilidade de professores. Certamente os sistemas optarão pelos itinerários para os quais dispõem de mais professores. Resolve-se, com prejuízo pedagógico e de forma econométrica, um problema de gestão e de carreira profissional. Os sistemas não mais se verão pressionados a realizarem concursos públicos para enfrentarem a falta de professores em determinadas áreas. Ademais, sabemos que está francamente em risco o exercício profissional dos professores de Sociologia e de Filosofia.

É importante salientar, ainda, que "os currículos dos cursos de formação de docentes terão por referência a Base Nacional Comum Curricular" (parágrafo $8^{\circ}$. do artigo 62 da LDB, emendado pelo artigo $7^{\circ}$. do PLC 34/2016). Dois prejuízos se colocam em vista. Primeiramente, como a BNCC definirá "objetivos de aprendizagem" (artigo 35-A, incluído na LDB pelo artigo $3^{\circ}$. do PLC 34/2016), a tendência dos currículos de licenciatura será selecionar conteúdos instrumentais a tais objetivos, o que pode comprometer a formação científica dos docentes. Em segundo lugar, mirando-se pelo ponto de vista pragmático dessa política, até que ponto a redução da carga horária referente à $\mathrm{BNCC}$ do currículo do ensino médio não causará a correspondente redução dos currículos das licenciaturas?

Quanto à formação técnica e profissional no ensino médio, defendida por educadores críticos como um direito dos estudantes, desde que integrada organicamente à formação geral e sem prejuízo desta, sua oferta volta a ser, agora, a negação do direito à educação básica. Isto, não só porque ela se converte em um itinerário à parte da formação geral comum, mas também porque os sistemas se interessarão em ofertá-la devido a algumas facilidades que a lei promove. Primeiramente, seus professores podem ser "profissionais com notório saber (grifo nosso) reconhecido pelos respectivos sistemas de ensino, para ministrar conteúdos de áreas afins à sua formação ou experiência profissional (...)" (artigo $6^{\circ}$. do PLC n. 34/2016, que emenda o art. 61 da LDB). Retira-se, assim, a barreira da formação docente para ser professor da educação técnica e profissional.

Em segundo lugar, este itinerário pode ser realizado em parceria com outras instituições (inciso I e parágrafo $8^{\circ}$. do inciso II, do artigo 36 da LDB, emendado pelo artigo $4^{\circ}$. do PLC n. 34/2016), levando o sistema de ensino a prescindir de seus próprios professores e da obrigação de estruturar e equipar escolas para este fim ${ }^{15}$. Sua oferta deverá considerar, ainda, "a possibilidade de concessão de certificados intermediários de qualificação para o trabalho, quando a formação for estruturada e organizada em etapas com terminalidade" (inciso II do artigo 36 da LDB, emendado pelo artigo $4^{\circ}$. do PLC n. 34/2016). Não se fala se o estudante que concluir etapas intermediárias da formação técnica e profissional, mesmo 
sem integralizar-se a carga horária do ensino médio, poderá prosseguir os estudos. A equivalência do ensino médio oferecido por qualquer um dos arranjos curriculares está prevista no parágrafo $9^{\circ}$. artigo 36 da LDB, emendado pelo artigo $4^{\circ}$. do PLC n. 34/2016.

De todo modo, o parágrafo 11 que se segue, prevê que, "para efeito de cumprimento das exigências curriculares do ensino médio, os sistemas de ensino poderão reconhecer competências e firmar convênios com instituições de educação a distância com notório reconhecimento", mediante diversas formas de comprovação, que incluem demonstração prática; experiência de trabalho supervisionado ou outra adquirida fora da escola; atividades de educação técnica oferecidas por outras instituições; cursos oferecidos por centros ou programas ocupacionais; estudos realizados em outros países; cursos realizados por EAD ou presencial mediada por tecnologia.

Ou seja, as múltiplas possibilidades de aproveitamento de estudos e experiências para a integralização curricular, sem qualquer outra regulamentação, poderão fazer com que o itinerário da formação técnica e profissional seja concluído sem ter sido cursado. Reduz-se, ainda mais, o que já foi reduzido, levando à possibilidade de se cursar o ensino médio em 1800 horas, já que o processo seletivo ao ensino superior "considerará [somente] as competências e as habilidades definidas na Base Nacional Comum Curricular (parágrafo $3^{\circ}$. do artigo 44 da LDB emendado pelo artigo $5^{\circ}$. do PLC 34/2016).

Com tantas desconstruções, há peculiaridades no Projeto de Lei que parecem abrir espaços para a recomposição do currículo como, por exemplo: a) os sistemas de ensino poderão compor "itinerário formativo integrado, que se traduz na composição de componentes curriculares da BNCC e dos itinerários formativos"; b) os sistemas de ensino, mediante disponibilidade de vagas na rede, possibilitarão ao aluno concluinte do ensino médio cursar mais um itinerário formativo" (respectivamente parágrafo $3^{\circ}$. e $5^{\circ}$. do artigo 36, emendado pelo artigo $4^{\circ}$. do PLC 34/2016).

A primeira possibilidade provavelmente será utilizada pelas escolas destinadas às elites, que resistirão em negociar o encurtamento da formação geral de seus filhos facilmente assimilável pela população que depende da escola pública - tal como fizeram no contexto da Lei n. 5.692/71, contribuindo para revogar a obrigatoriedade de formação profissional no $2^{\circ}$. grau por meio da Lei n. 7.044/82. A segunda possibilidade, que atrela uma possível escolha do estudante à condição do sistema de ensino, talvez seja procurada por aqueles que constatarem na prática o prejuízo da formação reduzida e fragmentada, ou mesmo a ineficácia do pragmatismo inerente a essa política, quando não se cumprirem as promessas de êxito nos exames de acesso ao ensino superior na área correlata ao itinerário cursado, ou ao emprego, após concluído o itinerário da formação técnica e profissional. Seria um problema do estudante se essa volta, contraditoriamente, o penalizar ao ampliar o tempo para concluir o que antes ele tinha direito de forma integrada.

Diante do exposto, é preciso novamente perguntar que jovens disseram que se interessam por este tipo de escola? Que jovens se interessam por tão pouco? Querem a metade da educação a que eles têm direito? Quem disse que os jovens não se interessam pelo ensino de ciências, de artes, de filosofia, de sociologia, de educação física, de história da África, e de outras línguas estrangeiras além do inglês (que passa a ser a única língua obrigatória a ser oferecida aos estudantes do ensino médio)? O que há, na verdade, é um jogo de linguagem, um jogo ideológico querendo nos convencer de que os interesses dos jovens são fugazes, que eles não têm projetos ou que esses são superficiais e instáveis, oferecendo-lhes, assim, a promessa de uma satisfação imediata tipicamente de uma lógica pós-moderna.

Os gestores e legisladores esquecem, ainda, que muitos desses jovens estudam e trabalham e, por isto, a jornada escolar de tempo integral não lhes será possível. O que fazer 
nessa situação? Na verdade, pouco teriam que se preocupar, pois, nos termos da Portaria que institui o Programa de Fomento à implementação de escolas de tempo integral, esses não teriam acesso às, no máximo, $4 \%$ de matrículas atuais de ensino médio que poderão ser fomentadas por este programa, restringidas, ainda, pelos critérios que dificilmente as escolas públicas conseguirão atender ${ }^{16}$. Ademais, não sabemos se a aprovação da PEC 55 inviabilizará esse programa, podendo, então, ser reconhecido como um componente do artefato ideológico utilizado pelo bloco no poder para se obter o consenso. Os filhos da classe trabalhadora, portanto, na melhor das hipóteses, terão acesso ao ensino médio mínimo, com uma formação mínima para uma vida igualmente mínima. Trata-se de uma política centrada na cultura do fragmento e do imediato, na economia do mínimo e na responsabilidade transferida para uma instância abstrata e volátil que é o mercado.

Sabemos que a escola passa por uma transição que tem a ver com a crise mais generalizada nos planos econômico, político e cultural. As gerações que estão no ensino médio hoje vivem em uma sociedade em mudança, em transformação, uma sociedade em crise e em risco. O ritmo da escola, a própria tradição da escola moderna, não permite a incorporação de mudanças imediatamente e não deveríamos esperar que o fizesse, pois, um dos sentidos da criação da escola é constituí-la como espaço de socialização do jovem na tradição de uma sociedade. Tradição no sentido da cultura que a sociedade construiu até o momento e que lhe dá coesão e, ao mesmo tempo, possibilita o conflito ${ }^{17}$. É assim que a sociedade se sustenta; é preciso conhecer, incorporar a própria tradição para se questioná-la e transformá-la. Então, de fato, a escola não muda com a mesma dinâmica que os contextos sociais e culturais, porque esse confronto entre a tradição e a mudança, o velho e o novo, é formativo. Ao mesmo tempo, a classe dominante, historicamente, subordinou a escola à economia, tornando o economicismo a ideologia hegemônica que tenta explicar e organizar suas funções. Mas é no plano de contradições que esta instituição se mostra, simultaneamente, reprodutora e resistente; por isto é também espaço de disputa.

Portanto, é preciso cautela com a ideia de que a escola não é atraente aos jovens, pois ao lado dessa afirmação se poderia perguntar: o que é atraente a esse jovem? Pode ser aquilo que lhe traz perspectivas, possibilidades formadoras. Ou podem ser também lógicas deformadoras? Assim, o principal desafio da escola está não só em tentar convergir com os interesses dos jovens, mas em educar seus próprios interesses. Os jovens, vindos de sua realidade - seja qual for, de uma vida burguesa, sofisticada, cara, ou de uma vida pobre, de carência - vão trazer os interesses que foram produzidos por essa realidade. Não cabe à escola reificá-los ou se adequar a eles. O que cabe à escola é, em se conhecendo tais interesses, confrontá-los com as necessidades formativas desses jovens, à luz de um projeto de sociedade. Isso tem a ver com currículo escolar. Pensar esse currículo nas dimensões da vida do estudante, implica trazer a ciência, o conhecimento, o trabalho e a cultura em todas as suas dimensões - a cultura juvenil, da mídia, erudita, enfim. É preciso haver, primeiro, um confronto para se poder construir o encontro entre projeto educacional e interesses do estudante.

É importante que a escola da educação básica e, em particular, do ensino médio, se pense nessa perspectiva. A contra-reforma do governo FHC falou intensamente do protagonismo juvenil, da contextualização do conhecimento, da interdisciplinaridade, inclusive da lógica da formação por competência, porque traria um ensino mais diretamente vinculado aos objetivos de aprendizagem. Essa já foi uma reforma feita em nome do suposto interesse do jovem. Uma parte dos educadores, na qual nos situamos, a criticaram porque tentava-se fazer mudanças do ponto de vista curricular sem considerar as questões estruturais da sociedade e da própria escola; e mais, as mudanças curriculares tinham como fim a 
adaptação do jovem à sociabilidade capitalista contemporânea, do incerto, da instabilidade e da flexibilidade.

Percebíamos a impertinência daquelas medidas instituídas pelo Decreto n. 2.208/97 e pelas DCN que o seguiram, porque elas também reificavam os interesses dos estudantes mas, na verdade, tornava a formação mais pragmática para o mercado de trabalho ou para a instabilidade da vida social. Mas as discussões construídas a partir de 2003redundaram na revogação desse decreto pelo de número 5.154/2004, posteriormente incorporado na LDB, e daquelas Diretrizes Curriculares, por meio das atualmente vigentes. Essas expressam o reconhecimento da necessidade de se repensar e se reorganizar o currículo do ensino médio tendo em vista a realidade dos seus estudantes, porém, sem negligenciar a finalidade educacional, que é formar um jovem na sua plenitude. O fundamento do ensino médio nesse sentido está na possibilidade de o estudante ter acesso e se apropriar do patrimônio científico, cultural, social, ético, político, produzido pela humanidade até então e, ao mesmo tempo, confrontar, questionar essa mesma tradição, do ponto de vista, inclusive, do seu tempo, do lugar onde se encontra, da forma como vê e se faz o mundo num determinado tempo.

\section{A título de conclusão}

Do que expusemos nesta análise podemos concluir que, tal como as ditaduras e golpes que se efetivaram ao longo do Século XX, o atual Golpe de Estado tem a sua determinação maior no âmbito econômico. O acirramento da crise no Brasil, num contexto de crise mundial do sistema capitalista, foi agravado por uma estratégia de obstaculizar o governo de poder governar. Além disso, a utilização da estratégia dos argumentos de sempre, de que a crise se devia ao excesso de gasto público no campo social.

Isto se patenteia pela rapidez na aprovação, pelos deputados e senadores representantes das diferentes frações do capital e da classe que o detém, da mais drástica medida de nossa histórica contra os direitos universais da classe trabalhadora, a PEC 55. Não há na história das nações, ousadia de violência econômica como o congelamento por vinte anos de novos investimentos em saúde, educação, cultura, etc. Como não há em nenhuma reforma da previdência social que coloque como patamar mínimo de quarenta nove anos de contribuição do trabalhador para poder gozar o direito de aposentadoria. O processo de espoliação da classe trabalhadora se completa com o anúncio dos termos da reforma trabalhista. Esta retira do trabalhador os poucos direitos mantidos mesmo por políticas neoliberais.

Ainda no plano econômico, o Golpe reitera a política de entrega do patrimônio nacional aos interesses da política Norte Americana. A entrega da Petrobrás e do pré-sal, por exemplo, juntamente com o atrofiamento da engenharia nacional, etc., aprofundam o projeto de capitalismo dependente. Por estas duas vias retoma-se a expansão da miséria e o acirramento das mais diversas formas de violência.

Todavia, como assinalamos ao final do item 2 deste texto, com base na análise de Florestan Fernandes, a "dominação que fecha o campo histórico da economia" também fecha o campo histórico da cultura em sentido amplo e, em particular, no atual Golpe de Estado, da educação. Não por acaso, depois de um ano de governo de Luiz Inácio Lula da Silva, justamente quando as forças sociais que o elegeram buscaram avanços na cultura e educação, dois movimentos que e expressam a nova organicidade da classe burguesa brasileira começaram a atuar na disputa da escola pública na gestão, no conteúdo, métodos e valores nos municípios e estados e no Ministério da Educação.

O movimento Escola sem Partido desde 2004 operava nas teses de defesa da escola e conhecimentos neutros, mas agora, ao longo do período de gestação do Golpe de Estado, 
avançou com a proposta do PL. 867/2015 no campo da intolerância com a diversidade e o diferente, e na criminalização do pensamento crítico. Vale-se da parte do Ministério Público e da Polícia para convocar autoridades de instituições universitárias a dar explicações sobre eventos que são parte da autonomia e da liberdade de pensamento. $\mathrm{O}$ fato mais recente é a instauração de um inquérito para criminalizar o Reitor da Universidade Federal do Rio de Janeiro. Outro fato emblemático foi a invasão, pela Polícia Federal, da Escola Florestan Fernandes, saltando os muros e atirando, numa operação para instaurar a pedagogia do medo.

Da mesma forma, o movimento Todos pela Educação, tendo quatorze dos maiores grupos econômicos brasileiros como fundadores, além de dezoito outras organizações ou institutos denominados como parceiros, neste mesmo período foi tomando cada vez mais espaço na direção ideológica e de conteúdos e métodos da educação pública.Estes dois movimentos articulados são os mentores da contra-reforma do ensino médio que serve ao projeto econômico e político do projeto societário defendido pelo Golpe de Estado de agosto de 2016.

Uma contra-reforma que se vale de uma suposta crise do ensino médio e de sua rejeição pelos jovens para manipular, com propaganda paga à grande mídia empresarial, a opinião pública. Por essa via, justifica a imposição autoritária por meio de Medida Provisória e as manipulações das leis vigentes, a começar pela LDB, chegando às Diretrizes do ensino médio e da educação técnica e profissional. Em realidade, a MP 746 e o PLC 34, de 2016, expressam o ideário ideológico do movimento Escola sem Partido e dos interesses do capital e do mercado.

O cerne da contra-reforma está na dissociação entre ensinar e educar e na condução de um processo de ensino com base na fragmentação e no pragmatismo. Reitera e incorpora as medidas dos períodos autoritários, sob ditaduras ou não, que afirmaram, ao longo do Século XX, a dualidade educacional e o acesso desigual ao conhecimento e à cultura, de acordo com a classe social.

Com efeito, se aprovadas, essas medidas farão o ensino médio regredir à lógica da Reforma Capanema da Era Vargas, pela qual os estudantes deveriam optar pelo ramo científico ou clássico, sendo a formação técnica e profissional destinada aos pobres, partida e sem equivalência para o curso superior, dividida, ainda, nos ramos do ensino comercial, industrial e normal. Retroage, também, às reformas da ditadura empresarial militar pautada pela ideologia do capital humano, no presente redefinida pela pedagogia das competências, num contexto em que o capital já não postula a integração de todos ao mercado, mas somente daqueles que se conformam dentro do que o mercado exige. Na ditadura, a formação técnica e profissional tornou-se um dos ramos igualmente destinados aos mais pobres, tendo moral e cívica como substituta das disciplinas com potencial de desenvolver a capacidade crítica dos estudantes.

O grande embate no processo de redemocratização na década de 1980 foi a defesa, primeiro na constituinte e depois no projeto de LDB, da escola pública, universal, gratuita, laica e unitária. Mesmo com todas as resistências, o grande ganho foi o de se garantir na LDB o ensino médio como a etapa final da educação básica. Entretanto, no governo de Fernando Henrique Cardoso, sob as teses neoliberais da ditadura do mercado, o Ministro da Educação Paulo Renato de Souza e sua equipe definem uma nova regressão com Decreto $\mathrm{n}$. 2.208/97, que torna a formação técnica e profissional um itinerário separado, paralelo ou posterior ao ensino médio e consagra em lei a dualidade.

Os operadores da contra-reforma do ensino médio, ao longo dos governos Lula da Silva e Dilma Rousseff, foram para organismos internacionais ou participaram de institutos privados ligados ao movimento Todos pela Educação. Guiomar Namo de Mello, um dos quadros mais ativos na gestão de Paulo Renato de Souza, como assinalamos acima, afirma 
que agora está se retomando o que foi interrompido nestes quatorze anos. Maria Helena Guimarães, por seu turno, o quadro mais importante da equipe de Paulo Renato de Souza, é Secretária Geral do MEC e a intelectual operadora desta e de outras medidas para a educação em seu conjunto.

O que se visa desconstruir são os pequenos avanços da LDB e a possibilidade criada pelo decreto 5154/04 de retomar o ensino médio integrado sob novas bases, tendo como fundamentos o trabalho, a ciência e a cultura e como perspectiva a travessia para a formação politécnica e omnilateral. A MP 746/2016 destrói a possibilidade da educação integral e de acesso ao patrimônio científico, cultural, social, ético, político, produzido pela humanidade, bases para a autonomia econômica e política para a grande maioria dos jovens que pertencem à classe trabalhadora.

Os argumentos de que o ensino médio será mais flexível e que atende aos interesses de escolhas dos jovens para mais rapidamente se inserirem no mercado de trabalho, são falsos e de um cinismo desmedido. A falsidade está no fato de que a contra-reforma é rígida nas disciplinas que conformam um ensino médio de bases científicas mínimas. De igual modo, falso é o argumento da possibilidade de escolhas entre os cinco itinerários, pois a situação financeira dos estados da união e as condições precárias das escolas denunciadas pelos movimentos das ocupações certamente serão agravadas pela PEC 55. O cinismo está no fato de que os autores dessa proposta e a quem representam têm seus filhos em escolas onde os currículos são amplos e as escolhas se dão em atividades complementares.

Trata-se de uma contra-reforma, portanto, que é contra os jovens da classe trabalhadora e que atende ao pensamento reacionário de que nem todos têm capacidade para o ensino superior ou, na pior das hipóteses, devem ser condicionados para aquelas áreas de menor prestígio econômico. A MP, pelo teor de um ensino médio de conhecimentos mínimos, restringe as escolhas de acesso ao ensino superior. Ao contrário de facilitar a entrada no mercado de trabalho condena a maioria dos jovens da classe trabalhadora, empregado ou não, ao trabalho simples de parco valor econômico.

Trata-se, finalmente, da contra-reforma exigida pelo Golpe de Estado consumado em 31 de agosto de 2016, que aprofunda o projeto de capitalismo dependente e que fecha novamente um circuito de nossa história com as marcas da dominação autoritária e consequente ruptura do Estado de Direito. Uma situação que, se não se estruturarem forças sociais capazes de rapidamente retomar o Estado de Direito, terá não só a geração presente de jovens, mas as futuras, com suas vidas truncadas e marcadas pela força da violência.

\section{Referências}

AGAMBEN, Giorgio. O Estado de Exceção. São Paulo: Boitempo, 2004

AGAMBEN, Giorgio. Maios sem Fim. Notas sobre a política. Belo Horizonte e São Paulo. Editora Autêntica, 2015

BOSI, Alfredo. Dialética da Colonização. São Paulo, Companhia das Letras, $20104^{\text {a }}$ edição.

BOURDIEU, Pierre. Sobre a Televisão. Rio de Janeiro: Zahar, 1997.

CÂNDIDO, Antônio. O caráter da repressão. outraspalavras.net/Brasil. Retirado em 25 de Janeiro de 2017.

CIAVATTA, Maria. A história do presente. Uma opção teórica marxista para a pesquisa em trabalho e educação? Rio de Janeiro, Texto apresentado no Seminário anual do Grupo de 
pesquisa/ CNPq - Trabalho História, educação e Saúde (THESE). 06 a08 de Dezembro de 2016 (no prelo).

COUTINHO, Carlos Nelson. A época neoliberal: revolução passiva ou contra-reforma? Novos Rumos, Marília, vol. 49, n. 1, p. 117-126, jan.- jun. 2012.

FERNADES, Florestan, Marx Engels História. São Paulo:Editora Ática, 1989.

FERNANDES, Florestan. A integração do negro na sociedade de classes. Rio de Janeiro: M.E.C., 1964. I

FERNANDES, Florestan. Sociedade de classes e subdesenvolvimento. Rio de Janeiro: Editora Zahar, 1968.

FERNANDES, Florestan. Capitalismo dependente e classes sociais na América Latina. Rio de Janeiro: Editora Zahar, 1973.

FERNANDES, Florestan. A Revolução Burguesa no Brasil: ensaio de interpretação sociológica. Rio de Janeiro: Zahar, 1974

FERNANDES, Florestan. A sociologia no Brasil. Petrópolis: Vozes, 1977

FRIGOTTO, Gaudêncio; CIAVATTA, Maria e RAMOS, Marise. Ensino Médio Integrado: concepção e contradições. São Paulo: Cortez e EPSJV/Fiocruz, 2005a.

FRIGOTTO, Gaudêncio; CIAVATTA, Maria e RAMOS, Marise. A política de educação profissional no governo lula: um percurso histórico controvertido. Educ. Soc., Campinas, vol. 26, n. 92, p. 1087-1113, Especial - Out. 2005b. Disponível em <www.cedes.unicamp.br>. Consulta em 24/01/2017.

GRAMSCI, Antonio. Concepção dialética da história. Rio de Janeiro: Civilização Brasileira, 1978.

GRAMSCI, Antonio. Os intelectuais e a formação da cultura. Rio de Janeiro: Civilização Brasileira, 1991.

IANNI, Octávio As metamorfoses do escravo. São Paulo: Difusão Européia do Livro, 1962

IANNI, Octávio. Escravidão e racismo. 1988. 2ª ed. São Paulo: Hucitec, 1988.

IANNI, Octávio. Raças e classes no Brasil. São Paulo: Brasiliense, 1972.

IANNI, Octávio. Temas em debate. Octávio Ianni: o preconceito racial no Brasil. Revista Estudos Avançados. Vol.18 n.50. São Paulo. Jan./Apr. 2004, p. 21-30

THOMPSON, E. A Miséria da Teoria ou um planetário de erros, uma crítica ao pensamento de Althusser. Rio de Janeiro: Zahar Editores, 1981.

WILLIANS, R. Cultura. Rio de Janeiro: Paz e Terra, 1992. 
${ }^{1}$ Professora dos Programas de Pós-graduação em Políticas Públicas e Formação Humana da Universidade do Estado do Rio de Janeiro (UERJ) e Educação Profissional em Saúde (EPSJV/Fiocruz). Especialista em Ciência, Tecnologia, Inovação e Produção em Saúde Pública da Fiocruz.

${ }^{2}$ Professor do Programa de Pós-graduação em Políticas Públicas e Formação Humana da Universidade do Estado do Rio de Janeiro (UERJ) e professor titular em Economia Política da Educação (aposentado) na Universidade Federal Fluminense

${ }^{3}$ Utilizamos o termo contra-reforma para definir a medida em curso, ao invés de "reforma", seguindo Coutinho (2012), quando este argumenta que o neoliberalismo busca apresentar como "reformas" o que são, na verdade, contra-reformas. Explica o autor que, para Gramsci, a contra-reforma é uma pura e simples "restauração". Diferenciando-se do conceito de revolução passiva - que compreende o momento de restauração (reação conservadora à possibilidade de uma transformação efetiva) e de renovação (no qual algumas das demandas populares são satisfeitas "pelo alto", através de "concessões" das camadas dominantes), na contra-reforma não existe o momento da renovação, mas sim, precisamente, o velho. Entendemos que a análise que apresentamos justificará a denominação que adotamos.

${ }^{4} \mathrm{O}$ referido Projeto de Lei de Conversão n. 34/2016 foi aprovado pelo Senado Federal no dia 08 de fevereiro de 2017, quando a análise exposta neste texto, tendo por base os documentos que foram apreciados pelo Congresso Nacional, já estava concluída.

${ }^{5}$ Doravante nomearemos os referidos instrumentos legais, respectivamente de MP, PLC e Portaria.

${ }^{6}$ A compreensão de Marx e Engels daquilo que definem como econômico é diametralmente oposta ao economicismo liberal ou a analises reducionistas. O econômico para os fundadores do materialismo histórico dialético refere-se à estrutura de relações sociais que os homens estabelecem - e os homens reais com suas ideologias, crenças valores - na produção e reprodução, pela ação vital do trabalho, de sua vida material.

${ }^{7} \mathrm{O}$ autor e a autora, em tempos diversos em institucionais universitárias como docentes pesquisadores e vinculados a organizações científicas, sindicatos e a movimentos sociais participaram e participam na defesa do Estado de Direito, da democracia e, como tal, dos direitos sociais e subjetivos da classe talhadora. O objeto de pesquisa de ambos tem sido a educação basca, em especial o ensino médio e a educação técnica de nível médio e profissional.

8 Luiz Fernando Veríssimo. Ódio. O Globo. Caderno de opinião. Rio de Janeiro, 25.06.2015 http://oglobo.globo.com/opiniao/odio-16546533\#ixzz3eAZnOCwa. Retirado em 20.01.2017

${ }^{9}$ Não nos ateremos aqui a este complexo debate sobre estas diferentes denominações e a questão, sobretudo, da raça. Sublinhamos, todavia, que raça, num sentido ontológico apenas existe uma, a raça humana e que, portanto, todas as formas de racismos são construções históricas de violência de seres humanos sobre outros.

${ }^{10}$ Neste particular a arte e a literatura, uma vez mais, vão mais longe, em explicitar aspectos que a ciência alcança apenas em parte. O escritor Antônio Cândido (1972), no texto "O Caráter da pressão", analisa a partir da literatura e cinema, a origem da instituição policial como instrumento da burguesia e cuja função é de arrancar dos acusados a verdade que interessa. Artigo publicado em janeiro de 1972 pelo Jornal Opinião e recuperado por outraspalavras.net/Brasil em 2016

${ }^{11}$ Resolução CEB/CNE N. 03/1998 e Parecer CEB/CNE N. 15/1998.

${ }^{12}$ Resolução CEB/CNE N. 02/2012 e Parecer CEB/CEN N. 05/2011. 
13 O Decreto n. 5.154/2004, que revogou o 2.208/97, recuperou o preceito da LDB de que o ensino médio, atendida a formação geral do educando, poderia prepará-lo para o exercício de profissões técnicas, no que se definiu no texto da lei como "forma integrada" da articulação entre educação profissional e ensino médio. A concepção de ensino médio integrado, por sua vez, que tem a forma integrada como uma possibilidade, mas não se reduz a ela, defende que a formação integrada na perspectiva da educação politécnica e omnilateral implica o trabalho como princípio educativo e o currículo orientado pela integração entre trabalho, ciência e cultura que possibilite a formação geral e técnica, científica e cultural, superando-se dicotomias e dualidades historicamente características da educação brasileira. Esta discussão se faz mais claramente em Frigotto, Ciavatta e Ramos (2005a).

14 Tal demarcação histórica refere-se ao início do primeiro mandato do Presidente Luiz Inácio Lula da Silva e o primeiro e último ano do segundo mandato da Presidente Dilma Rousseff. Apesar do percurso controvertido (Frigotto, Ciavatta e Ramos, 2005b) e lento traçado pelas referidas políticas certamente este foi o período no qual mais se conseguiu avançar conceitualmente em relação ao ensino médio. Em outro texto ainda no prelo, Ramos analisa as tentativas de avanço (2003 e 2004), os retrocessos e a retomada (2012 a 2014) de ações dirigidas ao ensino médio no Brasil, neste último caso, em especial como o Pacto pelo Fortalecimento do Ensino Médio.

15 Lembramos que, ao contrário do que expomos, os atuais Institutos Federais de Educação, Ciência e Tecnologia, antigas Escolas Técnicas e Agrotécnicas Federais, se tornaram instituições de elevada qualidade justamente porque constituíram seu quadro próprio de professores bem formados e com titulação em nível de pós-graduação, vinculados em regime de dedicação exclusiva e com salários justos. Também equiparam seus laboratórios, possuem bibliotecas com acervo de qualidade, além de auditórios, quadras esportivas, etc; e, mesmo com as contradições, buscam manter o ensino de artes, filosofia e sociologia em seus currículos. Com isto, elas foram acusadas de elitistas na década de 1990, pois a concorrência dos estudantes por uma vaga numa escola pública, gratuita e de qualidade, resultava no ingresso daqueles melhor formados, advindos de frações médias da classe trabalhadora. Com o argumento de se voltarem para suas finalidades originais que era a formação de técnicos para o mercado de trabalho, a contra-reforma de FHC tentou acabar com a oferta do ensino médio nessas instituições e torná-las mais pragmáticas. A velha lógica da classe dominante de que o ensino para a classe trabalhadora não pode ser de qualidade. Os governos de Luís Inácio Lula da Silva e de Dilma Rousseff voltaram a valorizar essas instituições, fortalecendo-as, ampliando-as e interiorizando-as. Conquistas que, certamente, no lastro da política em análise, estão fortemente ameaçadas e elas sofrerão o ataque de serem muito onerosas e de que a formação técnica e profissional pode ser oferecida com menos recursos e em parceria com o setor privado. Afinal, a história, quando se repete, é como farsa ou como tragédia. Estamos muito próximas desta última.

${ }^{16}$ Informação prestada pelo Prof. Ramón de Oliveira, da UFPE, em mesa de debate promovida pelo ASDUFPE, compartilhada com Marise Ramos, no auditório do Sindicato, em 20/10/2016.

${ }^{17}$ Aqui nos inspiramos um pouco em Gramsci (1978), Williams (1992) e Thompson (1981).

Recebido: Fevereiro/2017.

\author{
Aprovado: Abril/2017.
}

